\title{
The impact of asthma management guideline dissemination on the control of asthma in the community
}

\author{
Robert L Cowie MD ${ }^{1}$, Margot F Underwood BN ${ }^{1}$, Sally Mack BComm ${ }^{2}$ \\ ${ }^{1}$ Calgary Asthma Program, University of Calgary, Calgary, Alberta; \\ ${ }^{2}$ Glaxo Wellcome Inc, Mississauga, Ontario
}

RL Cowie, MF Underwood, S Mack. The impact of asthma management guideline dissemination on the control of asthma in the community. Can Respir $\mathbf{J}$ 2001;8(Suppl A):41A-45A.

OBJECTIVE: To measure the impact of asthma management education on the control of asthma in the community. DESIGN: A cross-sectional study comparing three communities.

SETTING: Three rural communities in southern Alberta. PATIENTS AND METHODS: A population sample of patients with asthma attending a pharmacy to fill a prescription for asthma medication were selected from three communities. Patients were asked to complete a questionnaire relating to their asthma management and control.

INTERVENTION: Three levels of asthma management education were provided in the three communities with populations of 6000 to 10,000 . The levels of education ranged from standard continuing medical education programs relating to the national asthma guidelines and a visiting asthma nurse educator to the establishment of an asthma clinic and a multiple-target, intensive education program for health professionals, town leaders, local media, schools and the public. The survey of the population with asthma was conducted approximately one year after the education program had been completed.

RESULTS: A total of 327 completed questionnaires were submitted. Analysis showed that there was no significant difference that could be attributed to the intervention in the management of asthma or in the level of asthma control among the patients from the three communities.
CONCLUSION: The more intense levels of education used to disseminate the content of the national asthma management guidelines did not translate into improved asthma control in the community.

Key Words: Asthma control; Clinical practice guidelines; Education; Guideline dissemination

\section{Impact de la diffusion des directives pour le traitement de l'asthme sur la maîtrise de cette maladie dans la communauté}

OBJECTIF : Mesurer l'impact de cours sur le traitement de l'asthme sur la maîtrise de la maladie dans la communauté.

MODÈLE : Étude transversale comparant trois communautés. CONTEXTE : Trois communautés rurales du Sud de l'Alberta. PATIENTS ET MÉTHODES : Un échantillon de population regroupant des sujets souffrant d'asthme se présentant à la pharmacie pour une ordonnance de médicaments contre l'asthme a été sélectionné dans trois communautés. Les sujets ont été invités à répondre à un questionnaire au sujet du traitement et de la maitrise de leur asthme.

INTERVENTION : Trois niveaux d'enseignement sur le traitement de l'asthme ont été offerts dans les trois communautés de 6000 à 10000 habitants chacune. Les niveaux d'enseignement variaient de programmes de formation médicale continue standard ayant trait aux directives nationales sur le traitement de l'asthme avec présence d'une infirmière monitrice, jusqu'à la création d'une clinique pour l'asthme et d'un programme d'enseignement intensif à plusieurs visées à l'intention des professionnels de la santé, des autorités municipales,

voir page suivante 
des médias locaux, des écoles et du public. Un sondage auprès de la population souffrant d'asthme a été effectué environ un an après la fin du programme d'éducation.

RÉSULTATS : En tout, 327 sujets ont répondu au questionnaire. L'analyse a révélé qu'il n'y avait aucune différence significative associée au type d'intervention thérapeutique pour
NNC, DO NOT COPY

位 tients des trois communautés.

CONCLUSION : Les niveaux plus énergiques de formation utilisés pour faire connaître les directives nationales sur le traitement de l'asthme ne se sont pas traduits par une amélioration de la maîtrise de l'asthme dans la communauté.
$\mathrm{C}$ linical practice guidelines for the management of asthma are now widely available (1-4). Concern has been expressed, however, that clinical practice guidelines have had little effect on the way physicians and other health professionals practise, and even less impact on patient outcomes $(5,6)$. While some clinical practice guidelines relate to diseases that are not common, this is not true for asthma, and yet many physicians are not familiar with the content of asthma management guidelines (7). Various methods have been developed to disseminate the content of these clinical practice guidelines. In Canada, national guidelines were first published in 1990 (8) and a second version appeared in 1996 (2). Contrary to the content of these publications, crisis management of asthma is still common, and many patients with asthma are not receiving regular anti-inflammatory medication $(9,10)$

In an attempt to examine the impact of asthma management guideline dissemination on the control of asthma in the community, we set out to provide different levels of asthma guideline dissemination in three communities and to measure the impact on the control of asthma in those communities. We identified three towns in Alberta in which different levels of interest in asthma had been apparent during earlier medical education programs. In conjunction with the physicians and other health professionals in these towns, we planned three different levels of education in asthma management using the national guidelines as a standard (2). In this study, we examined samples of the population with asthma from each of these towns to determine whether these education programs had had an impact on these populations.

\section{PATIENTS AND METHODS}

Three areas incorporating one or more closely adjacent towns were selected for this study. They will be identified as towns $\mathrm{A}, \mathrm{B}$ and $\mathrm{C}$, and are situated in the southern part of $\mathrm{Al}-$ berta. These centres were chosen because they were far enough from Calgary - the nearest major centre - that referral to Calgary specialists would be limited to exceptional cases, and they were close enough to allow the investigators to travel there and back to Calgary in one day. The towns were sufficiently far from each other - one south, one north and the third west of Calgary - to ensure that there would be little or no communication among the health care communities of the towns.

Ethics approval was obtained for this study from the University of Calgary's Conjoint Health Research Ethics Board and from the regional health authority for each of the three towns.

\section{Interventions}

Continuing education: Each of these towns had been provided with basic education in asthma management (Table 1). This basic education included several conventional medical education programs directed at the physicians in the area, and public education forums attended by interested members of the community, members of the population with asthma and their families, and some health professionals. Copies of the 1996 Canadian Asthma Consensus Conference recommendations (2) were widely distributed to physicians in the three towns, and additional copies were made available at all educational meetings.

Nurse educator program: In a one-year project, a nurse educator had visited each of the towns at six-week intervals to assess and educate patients with asthma referred by the local physicians. In each town, she had offered to educate a local health professional to continue the program at the end of one year. A written report regarding each patient referred for assessment and education was submitted to the referring physician. The report included suggestions arising from a review of the observations by the nursing and medical staff of the Calgary Asthma Program. The report was intended not only to provide information pertinent to the patient who had been assessed but also to provide general educational information about asthma in the context of the topics raised by the referred patient.

No further intervention was offered to town A, the biggest of the three towns with a population of 9200 .

Asthma program development: Towns B and C had expressed an interest in developing a patient asthma education program, and this was facilitated by training their personnel at the Calgary Asthma Program. Staff from the Calgary Asthma Program met with their counterparts from towns B and $\mathrm{C}$ to discuss the structure and function of the proposed asthma education programs. The staff of the proposed programs attended the Calgary Asthma Program to obtain hands-on experience in assessing and educating patients with asthma. They were observed and instructed in the process of patient assessment, education and counselling. Written material including questionnaires developed by the Calgary Asthma Program, videotapes and placebo inhaler devices were made available for them to use or to modify for their own programs. Instruction was provided in the use of asthma inhaler devices, peak flow and symptom monitoring, the development and use of action plans, and the use of spirometry. Documentation and other information were provided concerning asthma-inducing agents, asthma triggers and, in particular, the issues of household animals and of first- and second-hand tobacco smoke exposure. No further intervention was offered to town B. 
TABLE 1

COPYRIGHT PULSUS GROUP ING. " DO NOT COPY

Summary of the components and levels of education provided for each of three Alberta towns surveyed for the effectiveness of asthma education

\begin{tabular}{lcc}
\hline Town A & Town B & Town C \\
\hline $\begin{array}{l}\text { Medical education programs } \\
\text { Visiting nurse educator }\end{array}$ & $\begin{array}{c}\text { Medical education programs } \\
\text { Visiting nurse educator } \\
\text { Development of an asthma clinic }\end{array}$ & $\begin{array}{c}\text { Medical education programs } \\
\text { Visiting nurse educator } \\
\text { Development of an asthma clinic }\end{array}$ \\
$\begin{array}{l}\text { Pharmacy-based sampling } \\
\text { and questionnaire }\end{array}$ & One year later & $\begin{array}{c}\text { Intensive asthma education of the public and } \\
\text { health professionals, and publicity campaign }\end{array}$ \\
\hline
\end{tabular}

TABLE 2

Comparison of the population with asthma in three Alberta towns one year after completion of an asthma education program

\begin{tabular}{|c|c|c|c|c|}
\hline & \multicolumn{3}{|c|}{ Education level } & \multirow[b]{2}{*}{$\mathbf{P}$} \\
\hline & $\begin{array}{c}\text { Town A - Basic } \\
(n=174)\end{array}$ & $\begin{array}{c}\text { Town B - Intermediate } \\
\qquad(\mathrm{n}=55)\end{array}$ & $\begin{array}{l}\text { Town } \mathrm{C}-\text { - Intensive } \\
\qquad(\mathrm{n}=98)\end{array}$ & \\
\hline Admitted for asthma in 12 months (\%) & $7.5^{\star}$ & 14.5 & 18 & 0.02 \\
\hline ED in 12 months (\%) & $22^{*}$ & 45 & 36 & 0.001 \\
\hline Using inhaled steroid (\%) & 55 & 67 & 72 & 0.008 \\
\hline Used prednisone in one year (\%) & $20^{*}$ & 36 & 28 & 0.03 \\
\hline Waking at night $(\%)$ & 52 & 49 & 42 & 0.3 \\
\hline Use of beta2-agonist more than once/day (\%) & 34 & 49 & 29 & 0.04 \\
\hline No inhaled steroid or regular beta 2 -agonist use (\%) & $30^{*}$ & 20 & 19 & 0.1 \\
\hline Missed work/school in three months (\%) & 12 & 16 & 10 & 0.5 \\
\hline
\end{tabular}

*Might suggest that this population had milder asthma. ED Attendance at an emergency department for asthma treatment

Intensive education program: In addition, town $\mathrm{C}$ was the target for a multipronged asthma education program. The education menu included an intensive full-day asthma course provided in the local hospital. This course, which had been developed by the Office of Continuing Medical Education of the University of Calgary, was designed for physicians with a high level of interest in asthma. The program was presented by a multidisciplinary team that included asthma nurse educators, respirologists, pediatric respirologists and family physicians. Local physicians played a role in determining the topics to be presented and were included in the teaching faculty. The director of nursing, hospital administration and medical records staff were represented or present at the course, and participated in its structure and planning. The audience included local physicians and representatives from other health professional groups including nurses, respiratory therapists and hospital pharmacists.

Other elements of the education program in town $\mathrm{C}$ were meetings, teleconferences, interviews, media releases and posters to inform the local media, town councillors, schools, police, emergency medical services and the general public about asthma and the primary message that the disease can be controlled.

Several public forums were held, and these were addressed by staff from the Calgary Asthma Program and their counterparts in the local community. These forums were also attended by local health professionals who played an active part in the presentation and especially in the discussion. Posters were placed throughout the community to advise the public about the asthma program. The local pharmacies were provided with information about asthma and inhaler devices, and educational material to distribute to their clients. Regular contact was maintained by telephone and in person with members of the Calgary Asthma Program who regularly visited the town to meet with pharmacists and the asthma clinic staff. Recent medical journal articles about asthma were sent to the asthma clinic staff, and they were invited to attend a provincial asthma conference. Physicians were invited to attend any asthma continuing education programs that were held in the southern part of the province. Opinion leaders in the community, other than health professionals, were identified and approached to ensure that they were familiar with the asthma program.

Outcome evaluation: One year after the end of the intensive education program in town $\mathrm{C}$, members of the population of each of the three towns who indicated that they had asthmaidentified when they attended a local pharmacy to fill a prescription for an asthma medication - were asked to complete a questionnaire if they had not done so previously. The questions addressed issues related primarily to the extent to which their asthma was controlled as defined by the Canadian asthma guidelines (2), with secondary information relating to their use of asthma medication. Each person who completed a questionnaire was given an asthma information book. An 
COPYRICHT PULSUS GROUP

administrative fee was paid to the pharmacist for each completed questionnaire.

The questionnaires were collected by the Calgary Asthma Program and evaluated to determine differences among the responses from each of the three towns.

Analysis: The data from the completed questionnaires were entered into a database and analyzed to determine whether the information concerning asthma control differed among the three centres. The expectation was that the data from town $\mathrm{C}$ would reflect a higher level of asthma control and more appropriate management of asthma than that in towns $\mathrm{A}$ and $\mathrm{B}$. The analysis was performed using Epi Info, Version 6 (Centers for Disease Control, USA). Continuous variables were analyzed using ANOVA or Kruskal-Wallis one-way ANOVA. Categorical data were analyzed using $\chi^{2}$ analysis.

\section{RESULTS}

A total of 327 completed questionnaires were received, of which 174 were from town A, 55 from town B and 98 from town $\mathrm{C}$. The mean age of the subjects was 42 years, and the population with asthma in town A (a control town) was younger (39 years) than those in towns $B$ ( 45 years) and $C$ (46 years) $(\mathrm{P}=0.004)$. In town $\mathrm{A}$, fewer of the patients (compared with the total subjects from towns B and C) had admissions and emergency department visits for asthma $(\mathrm{P}=0.0002)$, and more patients used neither beta2-agonists nor inhaled corticosteroids regularly $(\mathrm{P}=0.03)$. The results are summarized in Table 2 . In no respect did the data from town C, compared with those from either of the control towns, show evidence of better asthma control. No finding suggested that an improved level of asthma control could be attributed to the intensive education program provided for town $\mathrm{C}$.

\section{DISCUSSION}

This study was designed to determine whether dissemination of the 1996 Canadian Asthma Consensus recommendations (2) would have a measurable effect on asthma outcomes in the community. We elected to examine a sample from the general population with asthma rather than a sample of patients identified by physicians in each town. We argued that the population sample would provide a more relevant indication of the impact of our interventions. Selecting pharmacies as a site for recruiting patients and restricting recruitment to those filling prescriptions for the treatment of asthma ensured that our sample reflected patients in the population with current asthma. It also seemed important to examine the impact after one year, which was considered a reasonable period to use to measure a stable response; others have reported a persistent improvement for up to 22 months after physician education (11). The period between the last intervention and the measurement was longer for towns $\mathrm{A}$ and $\mathrm{B}$, which would have exaggerated the effect had the final intensive intervention in town $\mathrm{C}$ been effective. The lack of an improved level of control in town $\mathrm{C}$ is, thus, a strong indicator of the ineffectiveness of the intensive and expensive intervention in that town.

The opening of a practice by a pediatric respirologist in
NC, DO NOT COPY

town $\mathrm{A}$ and the departure of a particularly enthusiastic family physician from town $\mathrm{C}$ may be thought to have neutralized differences between these towns. However, the family physician from town $\mathrm{C}$ left after the completion of the intervention, and the presence of a single pediatric specialist in a centre of 9200 people would not have been expected to have a major influence on a predominantly adult sample of those with asthma in the general population of that town.

We have no data to show that the subjects in our sample populations had a comparable level of asthma control at the start of the study. We recognized that a segment of the population of town A were young adults living and working in the area near the Rocky Mountains to enjoy hiking, climbing and skiing. In other respects, there is no plausible reason for believing that the populations or environments of the towns differed in a way that would affect the severity of the asthma. On comparing our data with those presented by Joyce and McIvor (9), who described asthma control in a population survey, the results are similar with regard to comparable information including the percentage needing emergency department treatment $(30 \%)$ and the percentage with daily asthma symptoms (approximately 50\%). Thus, it seems that our subjects reflect the national average and it is unlikely that any major difference existed in the severity of asthma among the three towns at the start of the study. Even if a significant difference had been present with more severe disease in the patients from town $\mathrm{C}$, an effective intervention should have produced levels of disease control above that of the national average.

We did not include a power analysis in the design of this study because no data for asthma control in a Canadian population sample were available. On the basis of our sample size and the data that we and others (9) have presented, our study has a power of $80 \%$ with a $95 \%$ CI to detect a difference of $15 \%$ in the number of subjects requiring emergency department treatment and $20 \%$ in the number of subjects with asthma control in town $\mathrm{C}$ compared with those in the two control towns. Although these changes are still far from optimal, we believe that they should have been achievable and relevant changes in the context of the intensity of the intervention.

Differences in the recruitment of participants varied in the towns due to varying degrees of enthusiasm on the part of the pharmacists that persisted notwithstanding the payment of an administrative fee of $\$ 5$ for each completed questionnaire, and repeated phone calls and visits by members of the investigatory team. There were no data to suggest that the different levels of participation reflected different attitudes among the populations of the three towns. It is possible that the proportion of customers recruited differed among pharmacies, but attendance at a given pharmacy is unlikely to have been related to the individual's degree of asthma knowledge or control.

The study's method of recruitment might have selected patients with more severe disease who would, thus, have been more likely to have prescriptions filled during the recruitment period. However, recruitment occurred at all three 


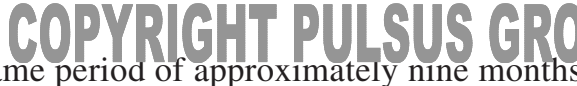
sites during the same period of approximately nine months and, thus, should have provided an opportunity for inclutant, the opportunities for inclusion were similar across the three sites.

On examination, our intervention appears to have conformed with generally accepted standards. Most of the reports relating to the dissemination of clinical practice guidelines have emphasized the importance of concordance of local, respected colleagues $(5,12-14)$. In the present study, all of the interventions were conducted with the collaboration of physicians and other health professionals in each town. The selection of town $\mathrm{C}$ as the site for an intensive intervention was driven entirely by the enthusiasm of several health professionals including physicians, a registered clinic nurse and a respiratory therapist in that town. Thus, notwithstanding the loss of one of the physicians from the area during the period after the intervention, there should - based on the enthusiasm of the local participation alone - have been a measurable impact on population asthma control.

We used methods recommended by others for the dissemination of clinical practice guidelines including 'evidence-based' guidelines $(15,16)$. We certainly used multifaceted methods for dissemination and performed these with enthusiasm with the close collaboration of local opinion leaders in a manner that has been recommended in several reports $(13,14,17)$.

Although there are reports of significant improvements in patient outcomes following the implementation of practice guidelines $(11,18)$, failure of the guidelines to produce a measurable impact on patient outcomes has also been documented $(6,10,19-21)$. In the present study, we have documented some better than average levels of inhaled corticosteroid use and a low level of reliance on inhaled beta2-agonists $(7,9)$. On the other hand, for a population sample, the degree of asthma control was poor in that half of our sample acknowledged waking at night with asthma and approximately onethird had required emergency department treatment for asthma in the preceding 12 months.

\section{CONCLUSIONS}

This study failed to show that the additional, intensive, multifaceted education program in town $\mathrm{C}$ resulted in a measurable improvement in asthma control in its population compared with those in the populations of the two control towns. Overall, the degree of asthma control in the sample populations of the three towns was better than that reported in a recent Canadian population survey with regard to the number of patients reporting use of inhaled corticosteroid, but it was similar in terms of symptoms, inhaled beta2-agonist use and use of emergency departments (9). Additional or different methods will need to be used to implement the recommendations for asthma management in the new Canadian Asthma Consensus report (1).
INC. DDONOTCOPY

ACKNOWLEDGEMENTS: This study was funded by Glaxo Wellcome Inc and the Calgary Asthma Program. We thank the Office of Continuing Medical Education and members of the Divisions of Respiratory Medicine in the Departments of Medicine and Paediatrics, Faculty of Medicine, The University of Calgary, and Astra Zeneca Canada Inc for their assistance with the education programs provided in this study.

\section{REFERENCES}

1. Boulet L-P, Becker A, Berube D, Beveridge R, Ernst P, for the Canadian Asthma Consensus Group. Canadian Asthma Consensus Report, 1999. CMAJ 1999;161(11 Suppl):S1-61.

2. Ernst P, FitzGerald JM, Spier S. Canadian Asthma Consensus Conference: Summary of recommendations. Can Respir J 1996;3:89-100.

3. British Thoracic Society and Others. The British Guidelines on Asthma Management: review and position statement. Thorax 1997;52(Suppl 1):S1-21.

4. National Heart, Lung, and Blood Institute. Expert Panel Report 2: Guidelines for the Diagnosis and Management of Asthma. Bethesda: National Heart, Lung, and Blood Institute, 1997.

5. Greco PJ, Eisenberg JM. Changing physicians' practices. N Engl J Med 1993;329:1271-4.

6. Worrall G, Chaulk P, Freake D. The effects of clinical practice guidelines on patient outcomes in primary care: a systematic review. CMAJ 1997; 156:1705-12

7. Doerschug KC, Peterson MW, Dayton CS, Kline JN. Asthma guidelines: an assessment of physician understanding and practice. Am J Respir Crit Care Med 1999;159:1735-41.

8. Hargreave FE, Dolovich J, Newhouse MT. The assessment and treatment of asthma: a conference report. J Allergy Clin Immunol 1990;85:1098-111.

9. Joyce DP, McIvor RA. Use of inhaled medications and urgent care services: study of Canadian asthma patients. Can Fam Physician 1999;45:1707-13.

10. Legorreta AP, Christian-Herman J, O'Connor RD, Hasan MM, Evans R, Leung KM. Compliance with national asthma management guidelines and specialty care: a health maintenance organization experience. Arch Intern Med 1998;158:457-64.

11. Clark NM, Gong M, Schork MA, et al. Impact of education for physicians on patient outcomes. Pediatrics 1998;101:831-6.

12. Hayward RSA. Clinical practice guidelines on trial. CMAJ 1997; 156:1725-7.

13. Partridge MR, Harrison BDW, Rudolph M, Bellamy D, Silverman M, for the British Asthma Guidelines Co-ordinating Committee. The British Asthma Guidelines - their production, dissemination and implementation. Respir Med 1998;92:1046-52.

14. Davis DA, Thomson MA, Oxman AD, Haynes RB. Changing physician performance: a systematic review of the effect of continuing medical education strategies. JAMA 1995;274:700-5.

15. Grol R, Dalhuijsen J, Thomas S, in't Veld C, Rutten G, Mokkink H Attributes of clinical guidelines that influence use of guidelines in general practice: observational study. BMJ 1998;317:858-61.

16. Hibble A, Kanka D, Pencheon D, Pooles F. Guidelines in general practice: the new Tower of Babel? BMJ 1998;317:862-3.

17. Feder G, Eccles M, Grol R, Griffiths C, Grimshaw J. Clinical guidelines: using clinical guidelines. BMJ 1999;318:728-30.

18. Grimshaw JM, Russell IT. Effect of clinical guidelines on medical practice: a systematic review of rigorous evaluations. Lancet 1993;342:1317-22.

19. Roghmann MC, Sexton M. Adherence to asthma guidelines in general practices. J Asthma 1999;36:381-7.

20. Weinberger M. Asthma - a problem of health care delivery. Is it time for a new paradigm? Allergy Asthma Proc 1999;20:57-65.

21. Premaratne UN, Sterne JAC, Marks GB, Webb JR, Azima H, Burney PGJ. Clustered randomised trial of an intervention to improve the management of asthma: Greenwich asthma study. BMJ $1999 ; 318: 1251-5$. 


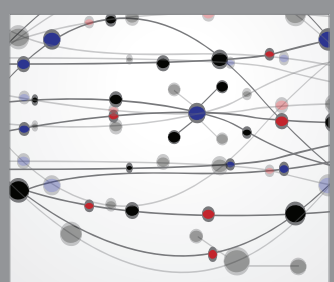

The Scientific World Journal
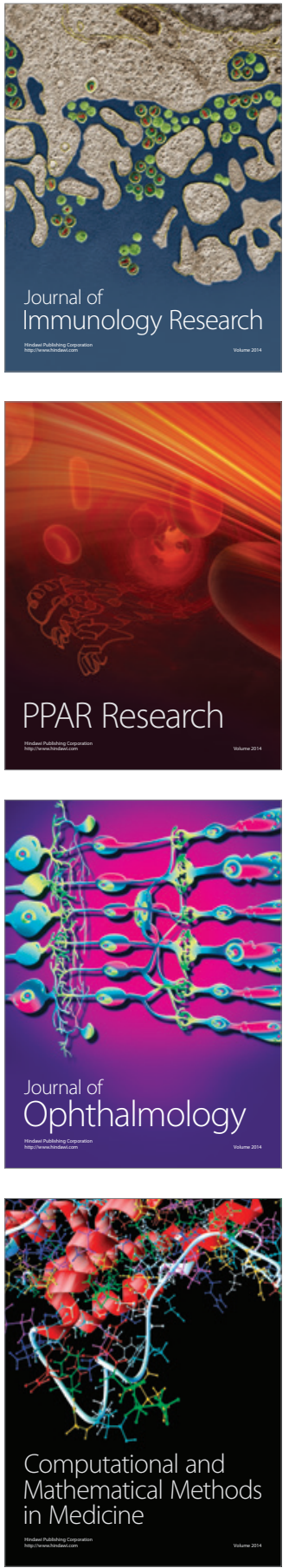

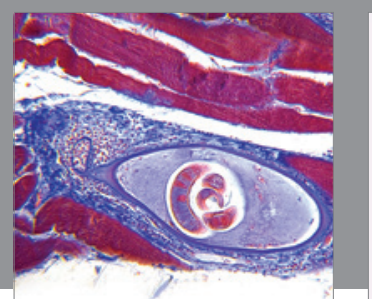

Gastroenterology Research and Practice

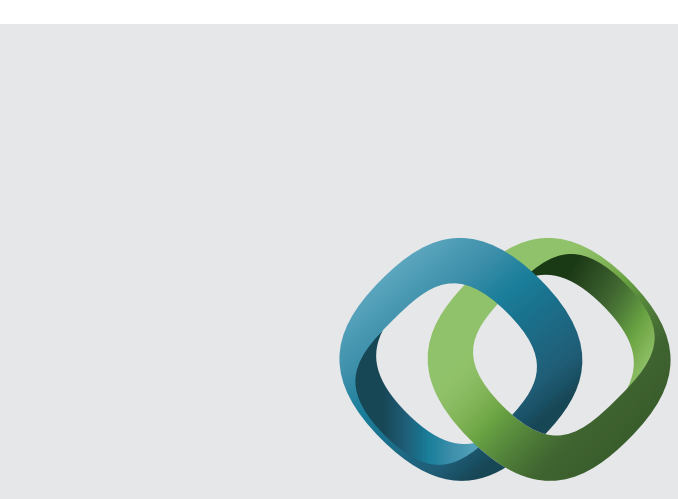

\section{Hindawi}

Submit your manuscripts at

http://www.hindawi.com
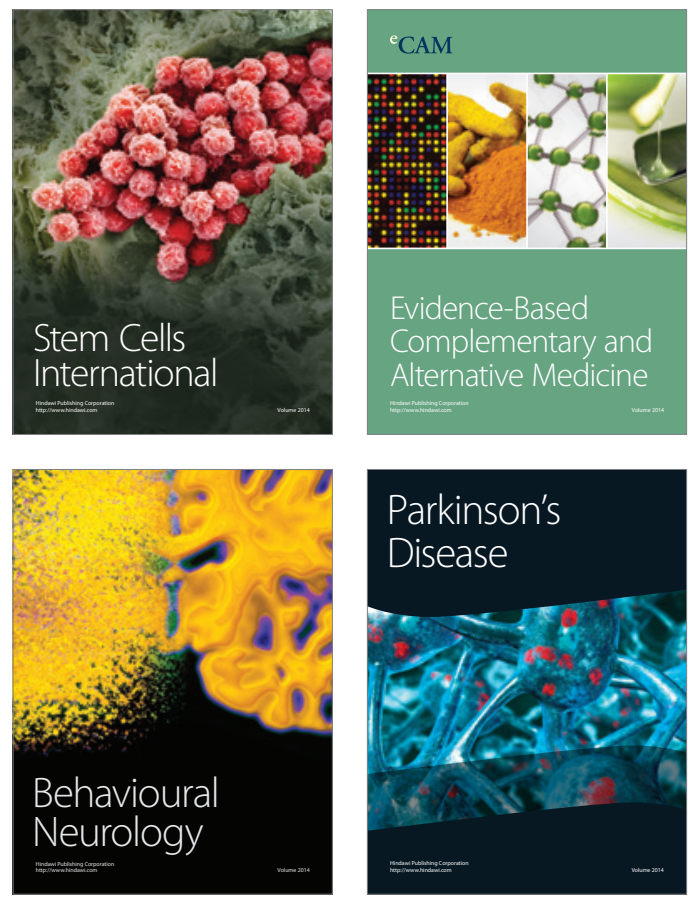
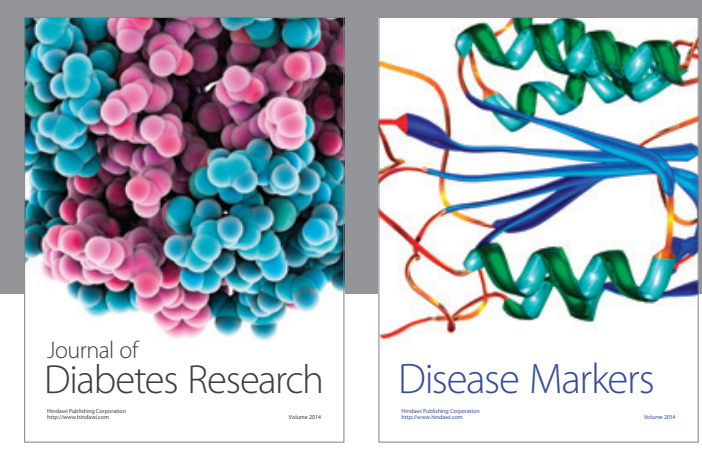

Disease Markers
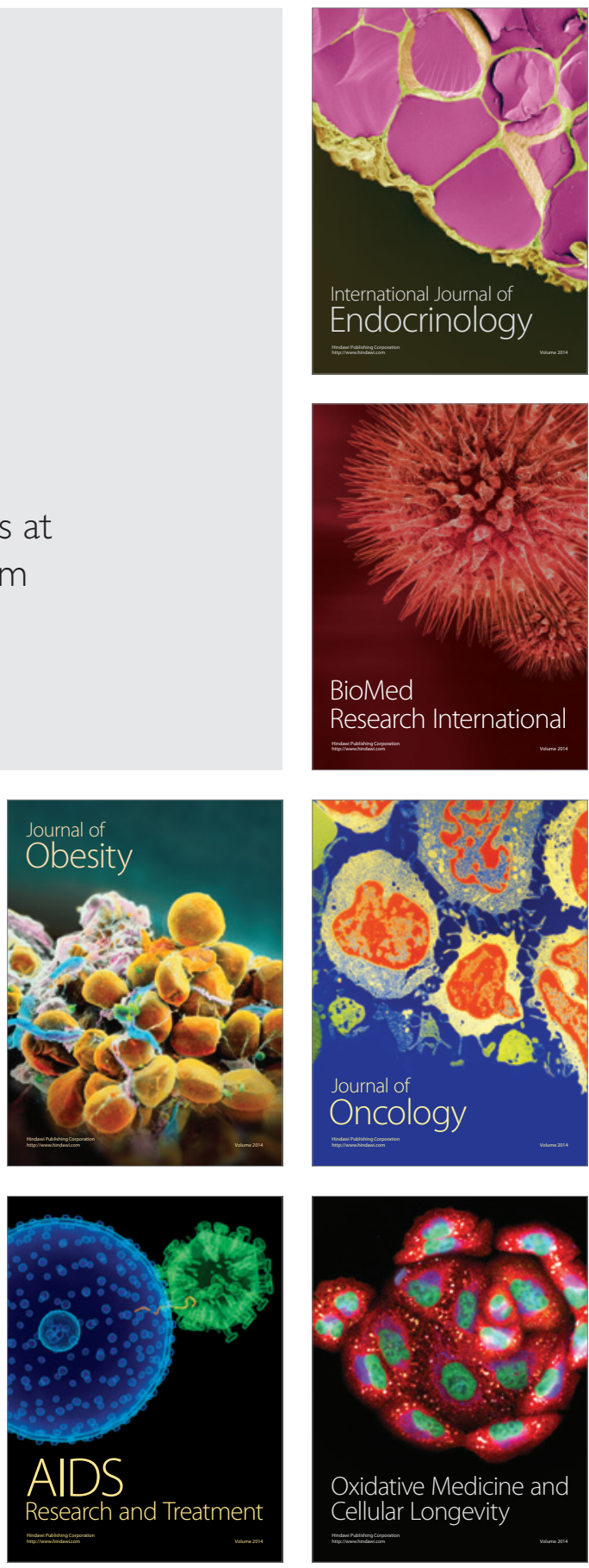